\title{
A Measurement of Performance: Student Involvement in Organization and Campus Environment
}

\author{
Hujjatullah FAZZLURRAHMAN', Dewie Tri WIJAYATI² , Andre Dwijanto \\ WITJAKSONO ${ }^{3}$
}

Article History: Received 20.01.2018 Received in revised form 09.03.2018 Accepted Available online 01.10 .2018

\begin{abstract}
This study aims to measure student achievement based on the activity that involved in the organization. In addition, the authors also examine the effect of campus environment on student achievement. This research consist 2 models, first model has independent variables (involvement of student and campus environment) and dependent variables (Grade Point Average). Second model, performance orientation as dependent variable.The method used in this study with a quantitative approach, using multiple regression to measure the models. The samples of this study are the students of Bachelor Degree Management. This study shows that the campus environment has an influence on the level or performance orientation student. The students involvement in the organization has negative affect to the Grade Point Average (GPA),. Not that because they actively organize to make the GPA is low. The campus environment has no effect on the GPA but the effect on the level of performance orientation.
\end{abstract}

Keywords:

(c) 2018 IJERE. All rights reserved

Student involvement, campus environment, student achievements, and performance orientation.

\section{INTRODUCTION}

The main ingredient in transforming science and value in society is the education system (Papaoikonomou, 2017). Otacioğlu (2016) argue musical performances can influence the audience emotionally and psychologically. Students are also influenced by achievements in the learning process. Learning can be done both inside and outside the classroom. Many people have assumed that higher education we have, will have a more positive impact (Fazlurrahman and Hadi, 2015). They can develop the mindset, values, beliefs, behaviors, personality, and lifestyle. Students must have a high competence and knowledge. After graduation, they have the experience to develop themselves in the workplace. Musical performances can influence the audience emotionally and psychologically. Students are also influenced by achievements in the learning process

University gives students the opportunity to engage in academic activities and student organizations inside or outside the campus. The decision of students to be involved in the organization have many considerations based on talents and interests (Fazlurrahman and Hadi, 2015). Chickering (1993) proposed that creating and maintaining a strong educational environment is an important task for higher education in the twenty-first century. Therefore, more and more people believe that through the experience of interacting with the environment, students can be developed and promoted.

This table will present Research Gap the study on student involvement in organizations and campus environment to student achievement. The first study conducted by Yu li (2007), the results of the study explained that the student involvement in the organization has a positive effect on student achievement. while the second variable is the campus environment has positive effect to student achievement but weak.

${ }^{1}$ Universitas Negeri Surabaya, hujjatullahfazlurrahman@unesa.ac.id, orcid.org/0000-0001-6095-0081 
Fazzlurrahman,H., Wijayati,D.T. \& Witjaksono,A.D.(2018). A measurement of performance: Student involvement in organization and campus environment. International Journal of Educational Research Review 3(4), 11-22.

Table 1 Research Gap

\begin{tabular}{|c|c|c|c|c|c|}
\hline Number & Title & Author & Variabl X & Variable Y & The study's result \\
\hline 1 & $\begin{array}{l}\text { The effect of student } \\
\text { involvement and college } \\
\text { environment } \\
\text { on students' academic } \\
\text { performance in four-year } \\
\text { univeristies in Taiwan }\end{array}$ & Min-Yu (2007) & $\begin{array}{l}\text { stuent } \\
\text { involvement } \\
\text { college } \\
\text { environtment }\end{array}$ & $\begin{array}{l}\text { Academics } \\
\text { performance }\end{array}$ & Positive but weak \\
\hline 2 & $\begin{array}{l}\text { Impact of Extracurricular } \\
\text { Activities on Students }\end{array}$ & $\begin{array}{l}\text { Wilson } \\
\text { (2009) }\end{array}$ & Extracurricular & $\begin{array}{l}\text { Academics } \\
\text { performance }\end{array}$ & Negative \\
\hline 3 & $\begin{array}{l}\text { Assessing the Relationship } \\
\text { between } \\
\text { Involvement and Academic } \\
\text { Performance in Higher } \\
\text { Education }\end{array}$ & $\begin{array}{l}\text {. Garland } \\
\text { (2010) }\end{array}$ & $\begin{array}{l}\text { student } \\
\text { involvement }\end{array}$ & $\begin{array}{l}\text { Academics } \\
\text { performance }\end{array}$ & $\begin{array}{l}\text { Positive but too } \\
\text { weak }\end{array}$ \\
\hline 4 & $\begin{array}{lr}\text { Relationship } & \text { between } \\
\text { Undergraduate } & \text { Student } \\
\text { Activity and } & \text { Academic } \\
\text { Performance } & \end{array}$ & $\begin{array}{l}\text { Hawkins } \\
(2010)\end{array}$ & Student activity & $\begin{array}{l}\text { Academics } \\
\text { performance }\end{array}$ & Negative \\
\hline 5 & $\begin{array}{l}\text { Effects of Involvement in } \\
\text { Clubs and Organizations on } \\
\text { ther Psychosocial } \\
\text { Development of First-Year } \\
\text { and Senior College Students }\end{array}$ & $\begin{array}{l}\text { Foubert and } \\
\text { Grainger } \\
(2006)\end{array}$ & $\begin{array}{l}\text { student } \\
\text { involvement }\end{array}$ & $\begin{array}{l}\text { Academics } \\
\text { performance }\end{array}$ & Positive \\
\hline 6 & $\begin{array}{l}\text { The Two -Year and Four- } \\
\text { Year Institution: Some } \\
\text { Selected Factors Associated } \\
\text { with AcademicPerformance. }\end{array}$ & Brian (1976) & $\begin{array}{l}\text { Institution } \\
\text { environment }\end{array}$ & $\begin{array}{l}\text { Academic } \\
\text { achievement }\end{array}$ & Positive \\
\hline 7 & $\begin{array}{lr}\text { SCHOOL } & \\
\text { ENVIRONMENT } & \text { AND } \\
\text { ACADEMIC } & \\
\text { ACHIEVEMENT } & \text { OF } \\
\text { STANDARD } & \text { IX } \\
\text { STUDENTS } & \end{array}$ & $\begin{array}{l}\text { Lawrence and } \\
\text { Vimala } \\
(2012)\end{array}$ & $\begin{array}{l}\text { School } \\
\text { environtment }\end{array}$ & $\begin{array}{l}\text { Academic } \\
\text { achievement }\end{array}$ & $\begin{array}{ll}\text { No } & \text { Significant } \\
\text { Relation } & \end{array}$ \\
\hline 8 & $\begin{array}{l}\text { Associations between } \\
\text { approaches to study, the } \\
\text { learning environment, and } \\
\text { academic achievement }\end{array}$ & $\begin{array}{l}\text { Al-Qahtani, } \\
\text { (2015) }\end{array}$ & $\begin{array}{l}\text { Learning } \\
\text { environment }\end{array}$ & $\begin{array}{l}\text { Academic } \\
\text { achievement }\end{array}$ & Signific ant Relation \\
\hline 9 & $\begin{array}{l}\text { College Residence and } \\
\text { Academic Performance: } \\
\text { Who Benefits From Living } \\
\text { on Campus? }\end{array}$ & $\begin{array}{l}\text { Turley } \\
\text { And Wodtke } \\
\text { (2012) }\end{array}$ & College Residence & $\begin{array}{l}\text { Academic } \\
\text { Performance }\end{array}$ & Negative relation \\
\hline
\end{tabular}

The second research was w ritten by Wilson (2009) that tested the effect of extracurricular on student achievement. The results of these studies explain that the effect is negative. Furthermore Garland (2010) examines the student involvement in the organization of student achievement. The results of this study are positive but weak

This can help to create an atmosphere of university academics and help students to learn. In this section, can be emphasized to students that the process is more important than the result. This paper examines whether the level of involvement of students who attend curricular activities / organizations have a different achievements to those who are not involved in student organizations. While the research conducted by Haw kins (2010) there was a difference in the results of resear ch that have a negative impact.

Another variable is the campus environment affect student achievement. This is a research by Brian (1976) and the correlation is a positive. While Turley and Geoffrey Wodtke (2012) research's is negatively 
Fazzlurrahman,H., Wijayati,D.T. \& Witjaksono,A.D.(2018). A measurement of performance: Student involvement in organization and campus environment. International Journal of Educational Research Review 3(4), 11-22.

correlated. Lawrence and Vimala (2012), the researcher of the relationship of environmental campus with student achievement and the findings are not a significant relationship. This is different to the one who written by Al-Qahtani (2015) which result is a significant relationship.

\section{Situation of the Problem}

Interaction with the environment can develop soft skills and hard skills. Both must involve universities to create a good and reliable generation. Hard skills are developed in class by lecturer, student organization while expanding soft skills to students. Student organizations have a diverse organization based on the activity of the same religion, science, service, sports, art and music. Student organizations give responsibility to carry out the organization (Fazlurrahman and Hadi, 2015). All student organizations are essentially responsible for training students to develop and improve the soft skills.

Campus environment can also affect student achievement. It is also delivered by Lawrence and Vimala (2012) that the environment also play an important role in the development of students personality. Students spend more time on campus, the campus environment is very influential in the planting of value to students.

\section{Aim of the Study}

Aim of the present study is to determine student if they involve in organization student and campus environment effect to GPA and performance orientation student.

\section{METHOD}

According to Sekaran and Bogie (2009) population is a group of people, activities, or something that caught the attention of researchers to investigate. In this study, the population is students of Bachelor Degree Management batch 2014, State University Surabaya with 198 students.

The sample is part of the population that reflects the population (Sekaran and Bogie, 2009). Samples were selected by students of Bachelor Degree Management 2014 Force, State University Surabaya that has actived over four semesters.

The author uses the method of sampling with the nonprobability sampling. Nonprobability Sampling is a sampling method that override population generalization. Beside that, it did not count any representation or representative of the population (have now and Bogie, 2009). The Category that has been selected is purposive sampling. Purposive sampling are researchers select a sample based on the characteristics of the samples in accordance with the purpose of study that is active students for four semesters, has been carrying out the registration, and never took a college leave.

Measuring variable used questionnaire. The questionnaire is divided 2 part and adopted from $\mathrm{Yu} \mathrm{Li}$ (2007) The first part is question for demography and second is statement of variable. first variable involvement in organization have nine indicator such as:

1. Lecturers can provide assistance to students.

2. Lecturer active attention to students.

3. Active students to ask for help from the lecturer.

4. Students are willing to exchange views with the lecturer.

5. I can have friend male or female.

6. I can find a close friend or companion.

7. I can find a friend to learn together.

8. I often get help from a classmate.

9. I can find no friends participating in various activities.

Second variable is campus environment that have many indicators such as:

1. Do you attend meetings held by a student organization?

2. Do you have a part time job?

3. Are you actively involved in student organization? 
Fazzlurrahman,H., Wijayati,D.T. \& Witjaksono,A.D.(2018). A measurement of performance: Student involvement in organization and campus environment. International Journal of Educational Research Review 3(4), 11-22.

4. Are you actively involved in the organization off-campus (Community Action, Religious groups, etc.)?

5. Have you met with leaders of the Faculty or Department to discuss the organization's activities?

6. Do you lead an organization on and off campus?

Based on Zhu et, al (2016) they made item for questionnaire for performance orientation that breakdown to 5 item :

1. I want to do well in a class because it is important to show my ability to my family, friends, employer, or others.

2. I set a high standard for my assignments in a course.

3. I keep a high standard for my learning. 0.78

4. If I can, I want to get better grades in a class than most of other students.

5. When studying a course, getting a good grade in a class is the most satisfying thing for me.

\section{Material}

The influence of student involvement in the organization of the achievements

Astin (1984) introduced the theory of involvement, in which he explains that students who are employed outside the college is more likely to succeed in college because of increased time demands. Several empirical studies support these findings by examining the obstacles hours of work on student engagement (Lundberg, 2004; Furr and Elling, 2000). Dugan and Komives (2010) found that $80 \%$ of students participate in at least one group experience before the end of year. This report describes a contradicts case that student involvement in campus activities are common in some cases but may not in others.

Baker (2008) found that the types of organizations in which students is a member does not affect the student's academic performance. In particular, membership in academic organizations related positively to academic performance. While engaging in recreational organizations, including Greece and intramural activities, negatively correlated with academic performance. Participation in athletics and religious student organizations, on the other hand, found no impact on students' academic performance

According to Patterson (2012), employers are more appreciative of competence in communication, adaptability, problem solving and teamwork skills. Several empirical studies emphasize the relationship between participation in student organizations and student development leadership skills (Dugan, 2011; Thompson, 2006; Ren and Bilodeau, 2005). The desirable skills are often introduced in an academic situation like in the classroom when they are reinforced in extracurricular activities such as student organizations (Patterson, 2012).

Academic and social efforts is a powerful determinant of student growth and learning outcomes, and the study has found that students and learning outside the classroom with the current conditions are interconnected in complex ways (Pascarella and Terenzini, 2005). A positive relationship between academic use of information technology and other engagement steps, particularly in the academic challenges, interactions between student-faculty, and active and collaborative learning, implying that "in volvement in one area often goes hand in other areas" Nelson Laird and Kuh (2005). Involvement in the study is measured both in general (the student experience as a whole) and specific (preparation of students for the exam, students in campus life, and the use of information technology student) (Yu li, 2007).

The influence of campus environment to student achievement

The campus environment is the extent to which the school set up to promote the safety and health of students, including topics such as physical plant, academic environment, provided support for physical and mental health and services, and the fairness and adequacy of the disciplinary procedure, because it is supported by relevant research and validity assessment (Law rence and Vimala, 2012).

Based on $\mathrm{Yu} \mathrm{Li} \mathrm{(2007)} \mathrm{institute} \mathrm{structural} \mathrm{characteristics} \mathrm{election} \mathrm{and} \mathrm{students} \mathrm{perceptions} \mathrm{of} \mathrm{their}$ learning environments are usually adopted as the action of the environmental factors that affect the results of college learning. Environment is valued with items that include an learning emphasis on various aspects of the questionnaire (Yu Li, 2007). Yu Li (2007), argues that the environmental has an impact on student 
Fazzlurrahman,H., Wijayati,D.T. \& Witjaksono,A.D.(2018). A measurement of performance: Student involvement in organization and campus environment. International Journal of Educational Research Review 3(4), 11-22.

learning and personal development, also studying the effects of interaction between student s and faculty on student learning and personal development. The higher the interaction between students and faculty both inside and outside the classroom, the better the development and student satisfaction.

Although the types of institutions is the best predictor of weak institutional achievements of the student or institutional characteristics are taken into account ( $\mathrm{Yu} \mathrm{Li}$, 2007). Li Yu (2007) studying the relationship betw een the institution's mission, student involvement and the output of the education .

\section{Student Achievement}

Setiaw an (2006), academic achievement is a term to indicate a success rate of achievement of a goal, because an effort of learning has been made by a person optimally. Powered by Bloom in Azwar (2002) which argues that academic achievement is to reveal the person's success in learning.

According to Law rence and Vimala (2012) student achievement is a measure of knowledge gained in formal education, usually indicated by test scores, class, grade point average and levels. Here, the achievement level of students assessed by achievement on tests. This research used GPA (grade point average) to measure student achievement.

\section{Performance Orientation}

Based on Harackiewicz and Elliot (1993) performance orientation people are interested in the demonstration of ability relative to other, whereas learning-oriented people tend to self-referenced, focusing on the developmend of skill and compentence relative to the task and their own past performance. Performance-oreintated people focus only on their present performamce relative to other, which is more likely to be inconsistent than performance relative to one's past performance (Gentry et al, 2006).

Hypothesis

The hypothesis of this study is

1. There is influences between student involvement in the organization and the student's achievement (GPA)

2. There is influences between a campus environmental influences on student achievement (GPA)

3. There is influences between student involvement in the organization and performance orientation

4. There is influences between a campus environmental influences and performance orientation
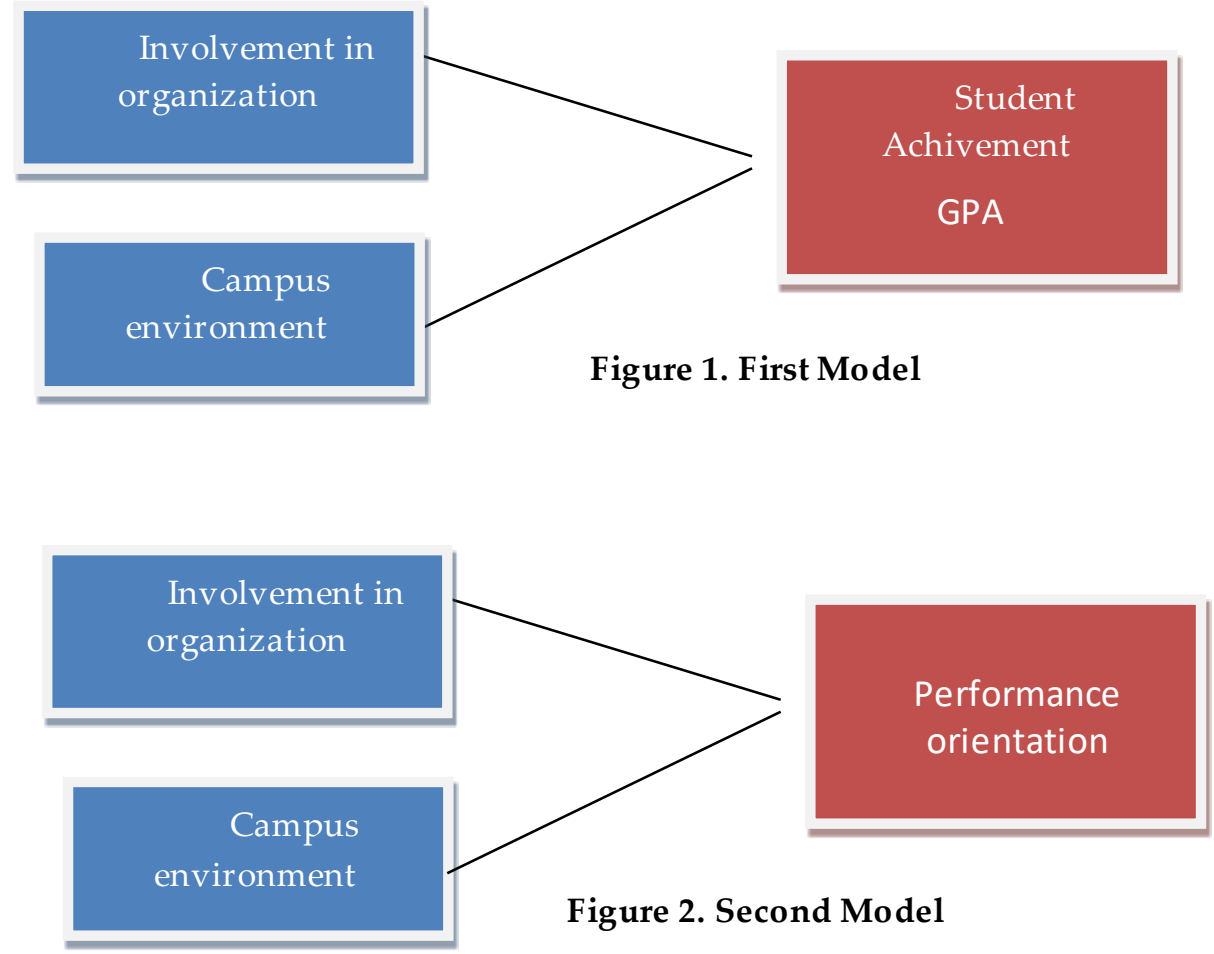

\section{Data Analyses}


Fazzlurrahman,H., Wijayati,D.T. \& Witjaksono,A.D.(2018). A measurement of performance: Student involvement in organization and campus environment. International Journal of Educational Research Review 3(4), 11-22.

Analysis of the data used is the influence test of using multiple regression test

\section{FINDINGS}

Respondents are students majoring in management in batch 2014. Questionnaires were returned to the author only 171 of the 200 questionnaires that we distribute to the respondent. While the 171 questionnaires that has collected, only 148 questionnaires that can be processed because there are some people who responded to the questionnaire is incomplete.

The author also provides demographic data of respondents to this study such as gender, involved in organizations, methods in the majors, the time spent when it is active in the organization, the selected organization, how many kinds of organizations that followed and the use of internet. The following table demographics.

Table 3. the demographics of the respondents.

\begin{tabular}{|c|c|c|}
\hline Number. & Demographic & Amount \\
\hline \multirow[t]{3}{*}{1} & Gender & \\
\hline & Male & 61 \\
\hline & Female & 87 \\
\hline \multirow[t]{3}{*}{2} & Active Organized & \\
\hline & Aktive & 65 \\
\hline & Not & 83 \\
\hline \multirow[t]{8}{*}{3} & Organization that followed & \\
\hline & Department / Major & 35 \\
\hline & Faculty & 11 \\
\hline & University & 3 \\
\hline & SMEs & 7 \\
\hline & Religion / social & 3 \\
\hline & Politics & 6 \\
\hline & Official & 1 \\
\hline \multirow[t]{6}{*}{4} & Department emphasis on & \\
\hline & Memorizing & 17 \\
\hline & Analysis & 65 \\
\hline & Integration & 12 \\
\hline & Evaluation & 12 \\
\hline & Application & 42 \\
\hline \multirow[t]{5}{*}{5} & $\begin{array}{l}\text { The time required outside of } \\
\text { class }\end{array}$ & \\
\hline & Less than 10 hours per week & 51 \\
\hline & 10 - 20 hours per week & 71 \\
\hline & 20 - 30 hours per week & 17 \\
\hline & More than 30 hours per week & 9 \\
\hline
\end{tabular}

When viewed from demographics, the number of women respondents is more than men in the amount of 87 of the 148 respondents. While the number of male respondents is 61 respondents. The number of respondents who are activein organizations is only 65 of 148 respondents, while inactive organized by 83 respondents. Organizations that many respondents are followed by is the organization at the department level, selected about 35 respondents.

Based on respondents answers to the question of your major emphasis on: memorization, analysis, integration, evaluation and application. Answer of the respondents is sur prising with the highest answer is analysis and appplication, by 65 and 42 respondents each. And the last question is the number of hours per week that you need for other activities outside the classroom that relate to academic programs such as learning, w riting, reading, research, laboratory work. The highest answer to this question is 10-20 hours per week and was selected by 71 respondents. 
Fazzlurrahman,H., Wijayati,D.T. \& Witjaksono,A.D.(2018). A measurement of performance: Student involvement in organization and campus environment. International Journal of Educational Research Review 3(4), 11-22.

Table 4. Student Activity

\begin{tabular}{|c|c|c|}
\hline Number & Activity & Amount \\
\hline \multirow[t]{6}{*}{1} & Curricular activities category & 15 \\
\hline & Religion & 30 \\
\hline & Scientific & 20 \\
\hline & Services & 41 \\
\hline & Art & 26 \\
\hline & Sports & 16 \\
\hline \multirow[t]{7}{*}{2} & $\begin{array}{l}\text { Hours per week are used for } \\
\text { organization }\end{array}$ & \\
\hline & 0 hours & 53 \\
\hline & 1 -10 Hours & 62 \\
\hline & $11-20$ hours & 20 \\
\hline & 21-30 hours & 4 \\
\hline & 31-40 hours & 4 \\
\hline & More than 40 hours & 4 \\
\hline \multirow[t]{6}{*}{3} & Kinds of organiation that followed & \\
\hline & 1 & 95 \\
\hline & 2 & 35 \\
\hline & 3 & 12 \\
\hline & 4 & 6 \\
\hline & More than 4 & 0 \\
\hline \multirow[t]{6}{*}{4} & Internet usage for non-academics & \\
\hline & 1 -10 hours & 53 \\
\hline & $11-20$ hours & 37 \\
\hline & 21-30 hours & 23 \\
\hline & 31-40 hours & 5 \\
\hline & More than 40 hours & 30 \\
\hline
\end{tabular}

Student activities in organizations dominated by the category of service and selected by 41 of the 148 respondents and was followed by a religious category. Time used for one week organized by 1-10 hours. This is the most selected answers of respondents.

Each respondent was only follow one organization, it is proved by the respondent answers has the major ity of 95 respondents. For the use of the Internet for non-academic activities of the majority of respondents chose 1-10 hours per week This is proven by the selection of respondents for 53 of the 148 respondents.

Analysis Model and Proving Hypothesis

The model used in this research is multiple linear regression analysis model. This research processing data using SPSS 18. The following are the results of multiple linear regression analysis:

Table 5. Results of Multiple Linear Regression Analysis

\begin{tabular}{|l|c|c|}
\hline Coeficient & B & Significant \\
\hline Contant & 6.492 & .000 \\
\hline Independent Variable & & \\
\hline Involvement in organization & -.189 & .031 \\
\hline Campus environment & .144 & .339 \\
\hline Dependent variable: GPA & & \\
\hline
\end{tabular}


Fazzlurrahman,H., Wijayati,D.T. \& Witjaksono,A.D.(2018). A measurement of performance: Student involvement in organization and campus environment. International Journal of Educational Research Review 3(4), 11-22.

From table 5. above, it can be obtained multiple linear regression equation as follows:

$$
Y=6.492+0,144 X 1-0,189 X 2
$$

From the results of the regression analysis in Table 4.9, it obtained this discussion as follows:

a. A constant value is 6,492 it can be interpreted that the meaning of the constants is a positive sign that the GPA of students is also influenced by other factors besides the campus environment and the involvement of the organization which is equal to 6.492 .

b. Involvement of the organization variable $\left(X_{1}\right)$ have a significantly negative effect on the students GPA $(Y)$ of -0.189 with a significance level of 0.031 which is smaller than 0.05 . This means that the higher the level of involvement of the organization it will affect the decline GPA student.

c. Campus environment variables $\left(\mathrm{X}_{2}\right)$ has no effect on the Students GPA (Y2) of 0.144 with significance level of 0.339 which is greater than 0.05 . That mean is the comfort of the campus does not affect to the students GPA.

As for the second multiple regression results are as follows:

Table 6. The Results of Multiple Regression Analysis at the 2nd models

\begin{tabular}{|l|c|c|}
\hline Coeficient & B & Significant \\
\hline Contant & 1.512 & .000 \\
\hline Independent Variable & & .509 \\
\hline Involvement in organization & -.031 & .000 \\
\hline Campus environment & .679 & \\
\hline $\begin{array}{l}\text { Dependent variable } \\
\text { performance orientation }\end{array}$ & & \\
\hline
\end{tabular}

From table 6 above, it can be obtained multiple linear regression equation as follows:

$$
Y=1.512+0,679 X 1-0,031 X 2
$$

From the results of the regression analysis in Table 4.4, it is obtained as the following discussion:

a. A constant value is 1.512 means that the meaning of the positive sign in constants is that the level of student achievement is influenced also by other factors besides supporting facilities, lectures and involvement of the organization which is equal to 1.512.

b. Involvement of the organization variable (X1) has no effect on the performance orientation (Y) of -0.031 with a significance level of 0.509 which is greater than 0.05 . That is the level of involvement of the organization does not affect to the level of student achievement.

c. Environmental Campus variable (X2) has an influence on the performance orientation (Y) at 0.679 with a significance level of 0.000 , which is smaller than 0.05 . That is the comfort of the campus environment affect the level of student achievement.

Feasibility Model

The test produces a value of $\mathrm{R}$ (correlation) and $\mathrm{R}^{2}$ (coefficient of determination) by multiple regression are as follows:

Table 7. Value of Correlation and Coefficient of Determination Regression

\begin{tabular}{|c|c|}
\hline \multicolumn{2}{|c|}{ Model summary } \\
\hline Adjusted R square & 0.021 \\
\hline
\end{tabular}


Fazzlurrahman,H., Wijayati,D.T. \& Witjaksono,A.D.(2018). A measurement of performance: Student involvement in organization and campus environment. International Journal of Educational Research Review 3(4), 11-22.

It can be seen that the contribution of independent variables that is consist of satisfaction of campus environment comfort $\left(\mathrm{X}_{1}\right)$, and the involvement of the organization $\left(\mathrm{X}_{2}\right)$ on dependant variable GPA $\left(\mathrm{Y}_{1}\right)$. Adjusted R Square is $0,021=2.1 \%$. These values indicate that the campus environment comvort $\left(X_{1}\right)$, and the involvement of the organization $\left(\mathrm{X}_{2}\right)$ affecting the GPA $\left(\mathrm{Y}_{1}\right)$ of $2.1 \%$. While the remaining 0.979 or $97.1 \%$ is influenced by other variables outside models that is used in this study.

Meanwhile, multiple regression testing using the second is as follows:

Table 8. Values and Correlation Coefficient of the Determination

Regression at the 2 nd model

\begin{tabular}{|c|c|}
\hline \multicolumn{2}{|c|}{ Model summary } \\
\hline Adjusted R square & 0.328 \\
\hline
\end{tabular}

Table 8. above can be seen the contribution of independent variables that is consist of satisfaction level of campus environment comfort $\left(X_{1}\right)$, and the involvement of the organization $\left(X_{2}\right)$ on the dependent variable performance orientation $\left(\mathrm{Y}_{1}\right)$. Adjusted $\mathrm{R}$ Square is 0.328 . These values indicate that the campus environment comfort $\left(\mathrm{X}_{1}\right)$, and the involvement of the organization $\left(\mathrm{X}_{2}\right)$ affect the value of Performance orientation $\left(\mathrm{Y}_{1}\right)$ with $32.8 \%$. While the remaining 0.672 or $67.2 \%$ is influenced by other variables outside models that be used in this study.

Proving hypothesis ( $t$ test)

$\mathrm{T}$ test results in research with multiple regression can be explained in the table below 4.7 this:

Table 9. T test result (Partial)

\begin{tabular}{|l|c|c|}
\hline Coeficient & $\mathbf{T}$ & Significant \\
\hline Contant & 11.135 & .000 \\
\hline Independent Variable & & \\
\hline Involvement in organization & .960 & .339 \\
\hline Campus environment & -2.175 & .031 \\
\hline Dependent variable : GPA & & \\
\hline
\end{tabular}

Based on the table 9. above can be deduced as follows:

a. The value of $\mathrm{T}_{\text {count }} \mathrm{X} 1$ is 0,960 supported by the value of the sign. amounting to 0,339 greater than 0.05. Then $\mathrm{H}_{0}$ is rejected and $\mathrm{H}_{1}$ is accepted, so we can say the campus variable comfort (X1) has no effect on the GPA (Y1).

b. The value $T_{\text {count }} \mathrm{X} 1$ for $-2,175$ supported by value sign. amounting to 0,031 smaller than 0.05 , then $\mathrm{H}_{0}$ Is rejected and $\mathrm{H}_{1}$ is accepted, so we can say the organization's involvement variable ( $\mathrm{X} 2$ ) have a significantly negative effect on the GPA (Y1) students.

The results of multiple regression $t$ test at the 2 nd can be explained in the table below 4.8 this:

Table 10. $t$ test result(Parsial)

\begin{tabular}{|l|c|r|}
\hline Coeficient & $\mathrm{T}$ & Significant \\
\hline Contant & 4.811 & .000 \\
\hline Independent Variable & & \\
\hline Involvement in organization & 8.370 & .000 \\
\hline
\end{tabular}


Fazzlurrahman,H., Wijayati,D.T. \& Witjaksono,A.D.(2018). A measurement of performance: Student involvement in organization and campus environment. International Journal of Educational Research Review 3(4), 11-22.

\begin{tabular}{|l|l|l|}
\hline Campus environment & -.662 & .509 \\
\hline $\begin{array}{l}\text { Dependent variable } \\
\text { performance orientation }\end{array}$ & & \\
\hline
\end{tabular}

According to the table 10. above can be deduced as follows:

a. The value of $\mathrm{T}_{\text {count }} \mathrm{X} 1$ at 0.8370 is supported by the value of the sign. 0,000 smaller than 0.05 then $\mathrm{H}_{0}$ and $\mathrm{H}_{1}$ are accepted, so we can say the campus environment comfort variable (X1) has a positive significant effect on the performance orientation (Y1).

b. The value of $\mathrm{T}_{\text {count }} \mathrm{X} 1$ with a value of -0.662 is supported by the value of the sign. amounting to 0.509 greater than 0.05 then $\mathrm{H}_{0}$ is accepted and $\mathrm{H}_{1}$ is rejected, so we can say the organization's involvement variable (X2) has no significant effect on the the performance orientation (Y1).

\section{RESULT, DISCUSSION, AND SUGGESTIONS}

This study uses four variables in determining hypothesis. The first model has two variable as an independent variable is the campus environment $\left(\mathrm{X}_{1}\right)$ and the involvement in the organization $\left(\mathrm{X}_{2}\right)$. Dependent variabel for this model is student achivement (GPA). The second model has two variable as an independent variable is the campus environment $\left(X_{1}\right)$ and the involvement in the organization $\left(X_{2}\right)$. Dependent variabel for this model is performance orientation. The following is a summary of the effect of independent variables on the dependent variables.

Table 11. Summary of the hypothes results for first model

\begin{tabular}{|c|l|l|}
\hline Number & Hypothes & Result / Effect \\
\hline 1. & $\begin{array}{l}\text { Involvement in organizations } \rightarrow \text { student achievement } \\
(\text { GPA })\end{array}$ & Negatively significant \\
\hline 2. & Campus environment $\rightarrow$ student achievement (GPA) & Not significant \\
\hline
\end{tabular}

The first hypothesis indicates that students involved in the organization has a significant negative effect on the GPA. The more students were actively organized the GPA will more getting down. This shows that there is a relationship with the opposite direction of involvement in the organization with the GPA. This is caused by the activity of students in the organization. They do not have plenty of time to learn. This was comfirmef by oleh Wilson (2009) and Hawkins (2010) that student involvement and student activity has negative relationship with academics performance

The second hypothesis shows that the campus environment has not significant on the GPA, it is clear that the campus environment as students interaction with professors, students and students do not have any influence. Based on Lawrence and vimala (2012), they found in research that school environment has not significant with academics achievement

Table 11. Summary of the hypothes results for Second model

\begin{tabular}{|c|l|l|}
\hline Number & Hypothes & Result / Effect \\
\hline $3 .$. & $\begin{array}{l}\text { Involvement in organizations } \rightarrow \text { Performance } \\
\text { Orientation }\end{array}$ & Not significant \\
\hline 4. & Campus environment $\rightarrow$ Performance Orientation & Positively significant \\
\hline
\end{tabular}

The third hypothesis shows that involvement in the organization has no effect on the level of achievement. This shows that the students involved in the organization is not achievement-oriented. The 
Fazzlurrahman,H., Wijayati,D.T. \& Witjaksono,A.D.(2018). A measurement of performance: Student involvement in organization and campus environment. International Journal of Educational Research Review 3(4), 11-22.

fourth hypothesis indicates that the campus environment has a significant effect on the level of achievement or achievement orientation. This proves the previous studies that conducted by Jack Brian (1976) that the campus environment impact on the degree / orientation on achievements. Al-qathani found from the research that learning organization has significant relationship with academic achievement. it is clear that the campus environment as students interaction with professors, students and students have influence to performance orientation.

This study shows that the campus environment influence student achievement (GPA). This shows that the interaction between faculty and students is necessary so that the student can improve his performance. In addition, interactions among students are also required to support the achievement that will be achieved. Involvement in the organization negatively affect the cumulative achievement index (GPA), as a matter of statistics because they are related negatively to those who active in the organization, then it makes their GPA dropped. Not that because they actively organize, it make the students GPA become low.

\section{REFERENCES}

Al-Qahtani, Mona, Faisal. (2015) Associations between approaches to study, the learning environment, and academic achievement. Journal of Taibah University Medical Sciences (2015) 10(1), 56e65

Astin, A.W. (1984). Student involvement: A developmental theory for higher education. Journal of College Student Personnel, 25, 297-308.

Baker, Christina N. (2008). Under-represented college students and extracurricular involvement: the effects of various student organizations on academic performance. Social Psychology of Education, 11, 273298. Accessed via http://files.eric.ed.gov/fulltext/ED104262.pdf on 29 march 2016 at 14.49

Brian, Jack (1976) The Two -Year and Four-Year Institution: Some Selected Factors Associated with Academic Performance.

Chickering, A.W. (1993). Education and Identity. San Francisco: Jossey-Bass Publishers.

Dugan, J. (Winter 2011). Students' involvement in group experiences and connections to leadership development. New Directions for Institutional Research: Assessment Supplement: 17-32.

Dugan, J. P. and Komives, S. R. (2010) Influences of college students' capacity for socially responsible leadership. Journal of College Student Development. 51, 525-549.

Fazlurrahman, hujjatullah and Hadi, Hafid (2015). A measurement of performance : student involvement in organization. Proceeding Gadjah mada International conference economics and business 2015.

Furr, S. R. and Elling, T. W. (2000). The influence of work on college student development. NASPA Journal, 37(2), 454-470.

Foubert, John D and Grainger Lauren U. (2006) Effects of Involvement in Clubs and rganizations on the Psychosocial Developmentof First-Year and Senior College Students accessed on 16 March 2016 at 15.15 via http://www.albany.edu/involvement/documents/effects of involvement.pdf

Garland, Azurdee M. (2010), "Assessing the Relationship between Student Involvement and Academic Performance in Higher Education". Masters Theses \& Specialist Projects. Paper 212.

Gentry, James W., Dickinson, John R., Burns, Alvin C., Ginnis Lee Mc., Park, Ju Young. (2006). The role of learning versus performance orientation when reacting to negative outcomes in simulation games. Developments in Business Simulation and Experiential Learning, Volume 33, 2006.

Harackiewicz, Judith M. and Andrew J. Elliot (1993), Achievement Goals and Intrinsic Motivation, Journal of Personality and Social Psychology Journal of Personality and Social Psychology, 65 (5), 904-915.

Haw kins, Amy L. (2010) Relationship between UndergraduateStudent Activity and Academic Performance. Thesis Purdue university, West Lafayette, Indiana, Amerika Serikat. 
Fazzlurrahman,H., Wijayati,D.T. \& Witjaksono,A.D.(2018). A measurement of performance: Student involvement in organization and campus environment. International Journal of Educational Research Review 3(4), 11-22.

Lawrence, arul and Vimala (2012). School Environment and Academic Achievement of standard IX. Journal of Educational and instructional studies in the world. Volume: 2 Issue: 3 Article: 22 ISSN: 2146-7463

Logan, Jennifer. Hughes, Traci. Logan, Brian (2013). Relationships between the degree and type of student organizational involvement and performance. Via http://www .atu.edu/jbao/student involvement.pdf. on 23 October 2015.

Lundberg, Carol A. (2004, Winter) Working and learning: the role of student involvement for employed students. NASPA Journal 41.2, 201-215.

Nelson Laird, T.F., \& Kuh, G.D. (2005). Student experiences with information technology and their relationship to other aspects of student engagement. Research in Higher Education,46: 211 -233.

OTACIOĞLU, S. G. (2016). Performance Anxiety and Academic Success Level Examination of Students in Turkey. International Journal of Educational Research Review ,1 (2).

Papaoikonomou, A. (2017). The impact of political socialization on students' behavior: Empirical research in schools of Central Macedonia in Greece. International Journal of Educational Resea rch Review, 2 (2).

Pascarella, E.T., \& Terenzini P.T. (2005). How College Affects Students: A Third Decade of Research. San Francisco: Jossey-Bass.

Patterson, Bryan (Spring and Summer 2012). Influences of student organizational leadership experiences in college students leadership behaviors," e-Journal of Organizational Learning and Leadership, 10(1), $1-12$.

Renn, K. A., and Bilodeau, B. L. (2005) Leadership identity development among lesbian, gay, bisexual, and transgender student leaders. NASPA Journal, 42, 342-367.

Sekaran, uma dan Roger Bougie.(2010). Edisi 5, Research Method For Business: A Skill Building Approach. John Wiley@ Sons, New York.

Setiawan, Yuli and Sudarto (2015), Prestasi Belajar Mata Pelajaran Ekonomi Kelas Unggulan Ditinjau Dari Aspek Pemilihan, Motivasi Belajar Dan Sarana Penunjang Pembelajaran accessed on 24 March 2015 at

https://publikasiilmiah.ums.ac.id/bitstream/handle/123456789/4886/6sudartoi.pdf?sequence=1

Thompson, M. D. (2006). Student leadership process development: An assessment of Contributing College resources. Journal of College Student Development, 47, 343-350.

Turley, Ruth N. López and Wodtke, Geoffrey (2010). College Residence and AcademicPerformance: Who Benefits From living on Campus. Urban Education 45(4) 506-532

Wilson, Nikki (2010) Impact of Extracurricular Activities on Students thesis master science in school councelling university of winconsin-stout pada tanggal 16 Maret 2016 pukul 15.37 melalui http://ww w2.uwstout.edu/content/lib/thesis/2009/2009 wilsonn.pdf

Yu Li, Min. (2007). Dissertation: The effect of student involvement and college environment on students' academic performance in four-year univeristies in taiw an. UMI Microform 3263114.

Zhu, Yue.Wing Au, Greg Yates. (2016). University students' self-control and self-regulated learning in a blended course. The internet and higer Education 30 hal 54-62. 